\title{
Potential for Shariah Arbitration in Commercial and Private Law
}

\author{
Aisha Mubarak*
}

\begin{abstract}
Arbitration is a form of Alternate Dispute Resolution (ADR). It is a way to resolve differences between parties outside of the judicial system. The dispute in an ADR mode will be adjudicated or mediated depending on the case brought by one or more persons, who are referred to as the Arbitrators. At the end of the arbitration process, parties can expect an outcome in the form of an award, which is an order for one party to pay the other party or an order for specific performance. An arbitration award is legally binding on the parties and is enforceable in a court of law.
\end{abstract}

Arbitration in civil law is gaining more ground because litigants prefer the arbitration forum to courts of law, even if the cost of arbitration is much higher than instituting and getting an outcome from a court action. The main reason for the popularity of ADR, like arbitration in general, is its flexibility in application of the law, freedom from the confines of procedure and the technicalities often associated with court actions and, most importantly, the efficiency which justifies the cost in the final picture. The mediation which precedes arbitration is now embodied as part of the ADR process.

In arbitration, the litigants will have a hand in choosing the applicable law, the Arbitrators, and the venue. Generally, an arbitration centre will set the procedural rules. Arbitration centres have become popular because of their efficiency and reliability. Trust is a key factor in becoming a good arbitration centre. The benefits of becoming an arbitration hub are numerous. They include development of the local legal system with input from arbitration, the recognition of talent as Arbitrators will be called for, and the integration of disciplines like academia, the judiciary, and industry as arbitration is not restricted by jurisdictional constrains.

\section{The Case for Shariah Arbitration}

In most jurisdictions, shariah is applicable to mainly private matters. Nevertheless, the past couple of decades have seen the rise of Islamic banking. One of the main issues when it comes to establishing a comprehensive framework for Islamic banking is the existence of a reliable ADR system. Until today, Islamic banking cases are still being litigated in the civil courts as contracts under the civil law. 
Leaving Islamic banking aside, the existence of a proper Shariah Arbitration forum would promote the use of shariah in other commercial areas. Arbitration allows parties to choose the applicable law for their transactions, which can be done at the time the contract is entered into, or even when the dispute arises. One of the main reasons English Law is popularly chosen as the applicable law for resolving disputes is because of the strength of its dispute resolution forums - be it in the courts or arbitration centres.

In my practice, I have encountered opportunities to introduce Shariah Arbitration as the ADR. In one example, the client was a Turkish garments manufacturer who wished to enter into a contract with a Malaysian start-up for an exclusive franchise-cum-dealership agreement. I felt that this contract would be suitable for Shariah Arbitration as this mode of dispute resolution was one where the parties could agree that any dispute in the contract be determined in accordance with the principles of shariah and be arbitrated either in Istanbul or Kuala Lumpur by a competent Shariah Arbitrator to be mutually selected by the parties. I did not see any issues in regards to the validity of the terms of the contract by shariah standards, as the contract was essentially for the supply of goods on order for a determined term with exclusivity granted to the party in Malaysia for valuable consideration. The possible legal disputes, if any, arising out of that contract would be issues of infringement of the exclusive franchise, quality of the goods, delivery related issues, non-payment/dispute on payment terms and amounts, supply, and perhaps damaged goods either from the factory or during shipment. In my opinion, all of these were within the competency of shariah. I even thought that the fact both parties did not have a common language provided even more of a reason for them to opt for shariah, which can be arbitrated in English, Turkish, or even Arabic, even though the contract itself was etched in English. Despite my best efforts, however, the parties rejected the proposal. I can say that the main reason was skepticism; the business world is so accustomed to the fact that commercial law is dictated by the civil system, whether it be English or European. Further, there is a lack of confidence that the shariah judicial system can deal with commercial matters, even though mu'amalat (transactions) is an established component of the shariah. As I mentioned above, even Islamic banking cases are arbitrated in the Civil Courts as civil contracts in accordance with secular contractual principles, procedure, and rules of evidence.

The second area where I can see potential for Shariah Arbitration is in private law. The potential in this area is greater than in commercial and public law matters as most Islamic countries implement shariah for family matters. Malaysia is a country where there is a separate and independent shariah judicial system, which comes under the jurisdiction of the individual states. This jurisdictional 
arrangement is protected by the Federal Constitution. However, this is not the case for countries like Turkey, which is a country with an almost entirely Muslim population but a secured secular legal system. Then there is also the diaspora of Muslims in the UK, Australia, Europe, and other such jurisdictions, where Muslims are subject to civil law for all their private matters. In the case of Muslims in a Muslim majority country, my view is that there should be a movement towards compulsory implementation of shariah in family and inheritance.

In the case of the Muslim diaspora, there is potential for elective Shariah Arbitration where the domicile jurisdiction is secular. I have received some inquiries from solicitors in the UK on the shariah position on marriage, divorce, and inheritance. In the case of matrimonial matters, the English courts are generally prepared to recognise marriages conducted in accordance with Islamic rites provided that there is some form of official confirmation of the marriage. This is in itself a complex matter which can invite various issues of law, depending on the facts. The main problem in dealing with this area is the inconsistency of standards, even the absence of any guideline, when determining the position according to shariah. Unlike the situation in a jurisdiction like Malaysia, which has a proper shariah regulatory system, civil courts are trying their best to understand and apply an alien jurisprudence within their court system and procedure. The situation is not ideal because the shariah and secular jurisprudences are of a different breed and kind altogether. In Chinese there is a saying: like a duck trying to talk to a chicken. Both legal systems have their own basis, sources, underlying philosophies, standards, and purposes. Shariah Arbitration, however, can fill this gap. In fact, more than just a filler of a void, I opine that the existence of Shariah Arbitration will promote the Islamic way of life and the preservation of its values in accordance with maqasid al-shari'ah.

\section{How can Shariah Arbitration become a Viable ADR in the Area of Private Law?}

In the case of marriage and divorce, which I refer to as 'matrimonial matters', we can divide cases into two categories depending on jurisdiction. As for the parties, I am only referring to Muslim couples and couples who have married in accordance with Islamic rites (in this case, there may be a party who is nonMuslim).

The first category of matrimonial matters is where the jurisdiction itself provides an adequate system of solemnisation and registration for an Islamic marriage and divorce. Under this category, the aim is to regulate, standardise, 
and register all marriages and divorces. In Malaysia, this jurisdiction is accorded to the Shariah Courts. Even in this category, the system has to face some loop holes, notably by having to evaluate the validity of marriages and divorces conducted and pronounced outside the proper register and court. In the case of marriages, shariah legislation recognises any marriage which has been conducted in accordance with Hukum Syarak (Islamic Rites) and accords those marriages, once recognised by the courts, all the rights under the law, including divorce, custody, and ancillary financial claims.

Having Shariah Arbitration, however, will bring these cases out of the court system and provide parties with an ADR. In practice, we are seeing more cases of inter-jurisdictional and conflict of jurisdiction issues in matrimonial matters brought to the Shariah Courts. In these circumstances, often the question of jurisdiction is played out in a larger litigation strategy to place a certain party in a better position than the other in respect of rights and claims. It is not a solution-based method, but rather becomes a game of strategy, often played out with principles of conflict between laws and jurisdiction. Moving ahead, with Shariah Arbitration in place, the greater end game would be towards a standard system of registration for all Muslim marriages and divorces across the globe.

The second category under matrimonial matters is faraid (Islamic estates). There is perhaps a larger scope in faraid for ADR than in other areas, including for Shariah Arbitration. In most estate cases, some sort of mediation is required, especially if the beneficial interest is wide and complex. Practitioners of faraid will understand how the principles of faraid recognise the rights of parents, preference of male heirs, rights of unborn children, polygamy, and the limits of the right to bequeath up to one third. We are noticing a growing realisation and acceptance of faraid as part of a complete Islamic way of life. In practice, however, there is an absence of reliable judicial forums outside of the court to determine shares, mediate claims, and resolve disputes between beneficiaries. In practice, lawyers are often having to run between the Shariah and Civil Courts to settle estate claims. For example, the determination of beneficiaries and their portions can be sought in the Shariah Courts, but the orders for distribution or for sale have to be obtained from the Civil Courts. In between, there can be claims on the estate in the Shariah Court, while caveats on the right to administer are filed in the Civil Court. Shariah Arbitration would be able to provide an ADR for claims disputes. Here I am not proposing to alter the administrative framework in estates, which primarily involves the Civil Courts, as their role is to ensure that requirements have been met. However, the ADR must be capable of being enforced extra judicially as assets may be located abroad and, if so, the Shariah Arbitration can reach beyond borders. 
The aim of this article has been to open up the discussion on Shariah Arbitration. There are many areas to be worked out but, I am sure, if there is a will, there is a way.

\section{Notes}

* Aisha Mubarak practices law in her own law firm, Aisha Mubarak \& Co., based in Cyberjaya, Malaysia. She has been in practice for 17 years, mainly in the area of real estate transactions and estate matters. She is also a Fellow of the Malaysian Institute of Company Secretaries and Administrators (MAICSA), an affiliate body to The Chartered Governance Institute, UK. She can be contacted at: aisha.mubarak@yahoo.com. 